\title{
Kajian Normatif Mengenai Penggunaan Discrecionary Power Bagi Pejabat Pemerintah Dalam Upaya Meningkatkan Kualitas Penyelenggaraan Pemerintahan
}

\author{
Oleh : \\ Tri Mulyani, A. Heru Heryanti, Endah Pujiastuti \\ Fakultas Hukum, Universitas Semarang \\ trimulyani@gmail.com, heru_nuswanto@yahoo.com,endahpujiastuti@yahoo.com
}

\begin{abstract}
ABSTRAK
Setiap negara hukum menuntut agar dalam penyelenggaraan pemerintahan harus didasarkan pada asas legalitas yaitu ketentuan undang-undang, termasuk juga Indonesia. Namun dalam hal melaksanakan tugas dan kewajiban penyelenggaraan pemerintahan agar dapat memberikan dan menjaga kualitas pelayanan publik serta mengusahakan kesejahteraan, di samping memberikan jaminan dan perlindungan bagi warga negara, maka tidak bisa hanya berpegang pada asas legalitas, karena semakin hari, perkembangan tuntutan pelayanan publik semakin kompleks dan beragam. Permasalahan demi permasalahan muncul dimasyarakat, dan pada kondisi seperti inilah muncul prinsip bahwa pemerintah tidak boleh menolak untuk memberikan pelayanan kepada masyarakat dengan alasan tidak ada peraturan perundang-undangan yang mengaturnya atau belum/tidak ada peraturan perundang-undangan yang dijadikan dasar kewenangan untuk melakukan perbuatan hukum. Oleh karena itu pemerintah diberikan kewenangan bebas melakukan tindakan/perbuatan tanpa harus terikat undang-undang yaitu discresionary power. Sehingga dalam penelitian ini akan dikaji lebih dalam tentang pentingnya penggunaan diskresi bagi pejabat pemerintah dalam penyelenggaraan pemerintahan. Metode penelitian yang dipergunakan diantaranya adalah jenis penelitian yuridis normatif, dengan pendekatan perundang-undangan dan konsep, spesifikasinya diskriptif analitis, pengumpulan data dengan studi kepustakaan dan akan dilakukan analisis secara kualitatif. Adapun hasil penelitian menunjukkan bahwa pentingnya penggunaan discresionary power bagi pejabat pemerintah dalam penyelenggaraan pemerintahan adalah sebagai alternatif untuk mengisi kekurangan dan kelemahan di dalam penerapan asas legalitas (wetmatigheid van bestuur), agar di samping pemerintah dapat melindungi dan menjamin kepastian hukum warga negara, pemerintah juga dapat memberikan pelayanan publik dan kesejahteraan bagi warga negara.
\end{abstract}

Kata Kunci : Penggunaan; Diskresi; Pemerintahan; Kualitas; Pelayanan Publik; 


\begin{abstract}
Each legal state requires that in the administration of the government should be based on the legality principle of the provisions of the law, including Indonesia. However, in terms of carrying out the duties and obligations of government administration in order to provide and maintain the quality of public services and prosperity, in addition to providing guarantees and protection for citizens, it can not just stick to the principle of legality, because the day, the increasingly complex demands of public services and diverse. Problems after problems arise in the community, and in such conditions the principle that the government should not refuse to provide services to the public on the grounds there is no legislation that regulate it or not / no legislation on which the authority to do legal action. Therefore the government is given free authority to perform actions / deeds without having to be bound by legislation that is discretion. So in this study will be studied more deeply about the importance of the use of discretion for government officials in the administration. The research method used is normative juridical research type, with approach of legislation and concepts, analytical descriptive specification, data collection with literature study and will be analyzed qualitatively. The results of the study indicate that the importance of discretionary power for government officials in the administration is an alternative to fill the shortcomings and weaknesses in the application of legality principle (wetmatigheid van bestuur), so that in addition to the government can protect and ensure legal certainty of citizens, the government can also provide public services and welfare for citizens.
\end{abstract}

Keywords: Usage; Discretion; Government; Quality; Public Service; 


\section{PENDAhuluan}

\section{A. Latar Belakang Penelitian}

Penyelenggaraan urusan pemerintahan dalam suatu negara hukum itu harus bersendikan pada peraturan perundang-undangan sesuai dengan prinsip yang dianut dalam suatu negara hukum yaitu asas legalitas. Asas legalitas dalam Hukum Administrasi Negara (HAN), sering dirumuskan dengan "Het beginsel van wetmatigheid van bestuur (prinsip keabsahan pemerintahan)". Asas legalitas ini mempunyai makna:"Dat het bestuur aan de wet is onderworpen (bahwa pemerintah tunduk kepada undang - undang)" atau "Het legaliteitsbeginsel hout in dat alle (algemene) de burgers bindende bepalingen op de wet moeten berusten (asas legalitas menentukan bahwa semua ketentuan yang mengikat warga negara harus didasarkan pada undang - undang)". ${ }^{1}$

Dalam asas ini, menghendaki bahwa hukum adalah sebagai pemegang komando tertinggi dalam penyelenggaraan negara. Dengan kata lain, bahwa yang menjadi pemimpin dalam penyelenggaraan negara adalah hukum (The rule of law and not of man). ${ }^{2}$ Sehingga dapat dikatakan bahwa pemerintah hanya dapat melakukan perbuatan hukum, jika mempunyai legalitas atau didasarkan pada UU.

Keberadaan asas legalitas di Negara Indonesia diatur secara tegas dalam Pasal 1 ayat (3) UUD NRI Tahun 1945 "Negara Indonesia adalah negara hukum”. Hal ini berarti mengandung makna bahwa Negara Indonesia sebagai negara hukum, harus berpegang teguh pada ketentuan asas legalitas tersebut, sehingga setiap tindakan atau perbuatan pemerintah harus berdasarkan dan sesuai dengan aturan hukum. ${ }^{3}$ Hal ini diharapkan bahwa dalam melaksanakan tugas penyelenggaraan pemerintahan tidak menyalahgunakan wewenang maupun tidak bertindak sewenang - wenang terhadap rakyat.

Sehubungan dengan hal tersebut di atas, pemerintah dalam melaksanakan tugas penyelenggaraan pemerintahan, diberikan fasilitas yang dikenal dengan instrumen pemerintah. Instrumen tersebut dapat berupa alat tulis menulis, sarana transportasi dan komunikasi, gedung gedung perkantoran, dan lain - lain, yang terhimpun dalam publiek domain (kepunyaan publik). ${ }^{4}$ Selain itu, pemerintah juga diperbolehkan menggunakan berbagai instrumen yuridis dalam

\footnotetext{
${ }^{1}$ Ridwan, Hukum Administrasi Negara Edisi Revisi (Jakarta: PT. Raja Grafindo Persada, 2014), halaman 91.

${ }^{2}$ H. Zaeni Asyhadie, dkk, Pengantar Hukum Indonesia (Jakarta: PT. Raja Grafindo Persada, 2015), halaman 198

${ }^{3}$ Ibid, halaman 199

${ }^{4}$ Ibid, halaman 125
} 
menjalankan kegiatan mengatur dan menjalankan urusan penyelenggaraan pemerintahan dan kemasyarakatan seperti peraturan perundang-undangan, keputusan - keputusan, perizinan, instrumen keperdataan, peraturan kebijakan atau Freies Ermessen atau dalam bidang pemerintahan dengan sebutan "Diskresionare Power" yang disingkat dengan istilah "Diskresi", dan lain - lain. Dalam penelitian ini akan difokuskan pada satu pembahasan mengenai instrumen yuridis yaitu penggunaan "Diskresi".

Istilah diskresi berasal dari bahasa Inggris "discretion" atau "Discrecionary Power". Discretion dalam Black's Law Dictionary mengandung arti “A public official's power or right to act in certain circumstances according to personal judgment and conscience. ${ }^{5}$ Bertolak dari pengertian tersebut dapat dikatakan bahwa penekanan pengertian tersebut diletakkan pada kekuasaan pejabat publik untuk bertindak menurut keputusan dan hati nurani sendiri, di mana tindakan tersebut dilakukan atas wewenang yang melekat pada jabatannya.

Menurut Prajudi Admosudirdjo, diskresi adalah suatu kebebasan bertindak atau mengambil satu keputusan menurut pendapatnya sendiri. ${ }^{6}$ Sedangkan Thomas J. Aaron dalam bukunya The Control of Police, sebagaimana dikutip oleh M. Faal, discretion diartikan, "discretion is power authority conferred by law to action on the basic of judgment or conscience, and its use is more on idea of morals then law". ${ }^{7}$ Artinya bahwa sebagai kekuasaan atau wewenang yang dilakukan berdasarkan hukum atau pertimbangan dan keyakinan dan lebih menekankan pertimbangan moral daripada pertimbangan hukum. ${ }^{8}$ Hal senada juga diungkapkan Marcus Lukman dan Nana Saputra.

Berdasarkan UU RI Nomor 30 Tahun 2014 tentang Administrasi, dijelaskan dalam Pasal 1 angka 9 bahwa diskresi adalah keputusan dan/atau tindakan yang ditetapkan dan/atau dilakukan oleh Pejabat Pemerintahan untuk mengatasi persoalan konkret yang dihadapi dalam penyelenggaraan pemerintahan dalam hal peraturan perundang-undangan yang memberikan pilihan, tidak mengatur, tidak lengkap atau tidak jelas, dan/atau adanya stagnasi pemerintahan.

Berdasarkan pengertian di atas dapat dikatakan bahwa diskresi adalah suatu kebebasan bagi Pejabat Pemerintah untuk bertindak atau mengambil satu keputusan menurut pendapatnya sendiri

\footnotetext{
${ }^{5}$ Bryan A Garner, Black's Law Dictionary, Seven Edition (West Group, ST. PAUL, MINN, 1999), halaman 479.

${ }^{6}$ Prajudi Admosudirdjo dalam R. Abdussalam, Penegakan Hukum Di Lapangan Oleh Polri (Jakarta: Dinas Hukum Polri, 1997), halaman 153

7 Thomas J. Aaron dalam M. Faal, Penyaringan Perkara Pidana Oleh Polisi (Diskresi Kepolisian), Cetakan Pertama (Jakarta: PT. Pradnya Paramita, 1991), halaman 16

${ }^{8} \mathrm{Ibid}$, halaman 16.
} 
dengan tujuan mengatasi permasalahan yang dihadapi dalam penyelenggaraan pemerintahan, tanpa terikat peraturan perundang - undangan.

Adapun tujuan penggunaan diskresi, dapat dilihat dalam Pasal 22 UU Administrasi Pemerintahan. Di dalam ketentuan pasal tersebut dijelaskan bahwa diskresi hanya dapat dilakukan oleh Pejabat Pemerintahan yang berwenang, dengan tujuan untuk:

1. Melancarkan penyelenggaraan pemerintahan;

2. Mengisi kekosongan hukum;

3. Memberikan kepastian hukum; dan

4. Mengatasi stagnasi pemerintahan dalam keadaan tertentu guna kemanfaatan dan kepentingan umum.

Bertitik tolak dari uraian di atas, penggunaan diskresi oleh Pejabat Pemerintah sering dapat dilihat dalam praktik penyelenggaraan pemerintahan dalam hal belum ada peraturan perundang undangan yang mengatur tentang penyelesaian in konkrito terhadap suatu masalah tertentu, padahal masalah tersebut menuntut penyelesaian dengan segera. Dapat diambil contoh, misalnya dalam hal menghadapi suatu bencana alam, atau menghadapi suatu wabah penyakit menular, maka aparat pemerintah harus segera mengambil tindakan yang menguntungkan bagi negara maupun bagi rakyat, tindakan mana semata - mata timbul atas prakarsa sendiri. ${ }^{9}$

Selain itu, dalam praktik penyelenggaraan pemerintahan, diskresi juga dilakukan oleh Pejabat Pemerintah dalam hal mana peraturan perundang - undangan yang menjadi dasar berbuat Pejabat Pemerintah memberikan kebebasan sepenuhnya. Dapat diambil contoh, misalnya dalam hal pemberian izin berdasarkan Pasal $1 \mathrm{HO}$ atau izin gangguan, setiap pemberi izin bebas untuk menafsirkan pengertian "menimbulkan keadaan bahaya" sesuai dengan situasi dan kondisi daerah masing - masing. ${ }^{10}$

Selain 2 (dua) hal tersebut di atas, dalam praktik penyelenggaraan pemerintahan, diskresi juga dilakukan oleh Pejabat Pemerintah dalam hal adanya delegasi perundang - undangan, maksudnya Pejabat Pemerintah diberi kekuasaan untuk mengatur sendiri, yang sebenarnya kekuasaan itu merupakan kekuasaan Pejabat yang lebih tinggi tingkatannya. Dapat diambil contoh, misalnya dalam hal menggali sumber - sumber keuangan daerah. Pemerintah daerah bebas untuk mengelolanya, asalkan sumber - sumber itu merupakan sumber yang sah. ${ }^{11}$

\footnotetext{
${ }^{9} \mathrm{Ibid}$, halaman 172

${ }^{10} \mathrm{Ibid}$, halaman 172

${ }^{11}$ Ibid, halaman 172
} 
Berdasarkan uraian tersebut di atas, dapat dikatakan bahwa penggunaan diskresi dapat dilakukan atas dasar hukum dan keyakinan, namun lebih jauh dapat dikatakan bahwa penggunaan diskresi lebih menekankan pada pertimbangan moral (norma moral) daripada pertimbangan hukum (norma hukum). Di mana norma moral berkaitan dengan tindakan tersebut dilakukan berdasarkan hati nurani, sedangkan norma hukum, berkaitan dengan wewenang dijalankan atas dasar undang - undang, sehingga dalam menilai suatu situasi konkrit diperlukan berbagai persyaratan bagi setiap Pejabat Pemerintah.

Berdasarkan uraian tersebut di atas, jelaslah kiranya bahwa dalam sebuah negara hukum menuntut agar setiap penyelenggaraan pemerintahan harus didasarkan pada asas legalitas yaitu ketentuan undang - undang. Namun dalam hal melaksanakan tugas dan kewajiban penyelenggaraan pemerintahan agar dapat memberikan dan menjaga kualitas pelayanan publik serta mengusahakan kesejahteraan, di samping memberikan jaminan dan perlindungan bagi warga negara, maka tidak bisa hanya berpegang pada asas legalitas, karena semakin hari, perkembangan tuntutan pelayanan publik semakin kompleks dan beragam. Permasalahan demi permasalahan muncul di masyarakat, dan pada kondisi seperti inilah muncul prinsip bahwa "Pemerintah tidak boleh menolak untuk memberikan pelayanan kepada masyarakat dengan alasan tidak ada peraturan perundang - undangan yang mengaturnya, atau belum/tidak ada peraturan perundang - undangan yang dijadikan dasar kewenangan untuk melakukan perbuatan hukum". ${ }^{12}$ Oleh karena itu pemerintah diberikan kewenangan bebas melakukan tindakan / perbuatan tanpa harus terikat undang - undang yaitu diskresi. Walaupun pemerintah diberikan kewenangan untuk bertindak bebas, namun penggunaan diskresi dalam suatu negara hukum, tidaklah dipergunakan tanpa batas. Penggunaan diskresi harus dalam batas - batas yang dimungkinkan oleh hukum yang berlaku (batasan yuridis).

\section{B. Rumusan Masalah}

1. Bagaimana pentingnya penggunaan discresionary power bagi pejabat pemeritah dalam upaya meningkatkan kualitas penyelenggaraan pemerintahan?

2. Apa yang menjadi batasan bagi pejabat pemerintah dalam menggunakan Discresionary Power dalam upaya meningkatkan kualitas penyelenggaraan pemerintahan ?

\section{Tujuan Penelitian}

${ }^{12}$ Ibid, halaman 172 - 173 
1. Untuk mengetahui pentingnya penggunaan discresionary power bagi pejabat pemeritah dalam upaya meningkatkan kualitas penyelenggaraan pemerintahan.

2. Untuk mengetahui batasan bagi pejabat pemerintah dalam menggunakan Discresionary Power dalam upaya meningkatkan kualitas penyelenggaraan pemerintahan.

\section{Manfaat Penelitian}

Hasil penelitian ini diharapkan dapat bermanfaat untuk kepentingan teoritis dan kepentingan praktis. Secara teoritis, hasil penelitian ini diharapkan dapat memberikan sumbangan pemikiran bagi ilmu pengetahuan, khususnya ilmu Hukum Administrasi Negara dalam kaitannya pentingnya penggunaan discresionary power bagi pejabat pemeritah dalam upaya meningkatkan kualitas penyelenggaraan pemerintahan. Secara praktis, hasil penelitian ini diharapkan dapat memberikan manfaat bagi pejabat pemeritah untuk memperluas wacana mengenai penggunaan Discresionary Power dalam upaya meningkatkan kualitas penyelenggaraan pemerintahan dan batasan yang dijadikan pedoman dalam penggunaannya.

\section{METODE PENELITIAN}

\section{A. Jenis Penelitian}

Jenis penelitian yang dipergunakan dalam penelitian ini adalah yuridis normatif, yakni penelitian yang difokuskan untuk mengkaji penerapan kaedah-kaedah atau norma-norma hukum positif. ${ }^{13}$ Tipe ini dipergunakan, mengingat bahwa obyek dalam penelitian ini adalah kajian secara normatif mengenai pentingnya penggunaan discrecionary power bagi pejabat pemerintah dalam upaya meningkatkan kualitas penyelenggaraan pemerintahan dan batasan yang dijadikan pedoman dalam penggunaan discrecionary power.

\section{B. Metode Pendekatan}

Sehubungan dengan tipe penelitian yang digunakan yakni yuridis normatif, maka pendekatan yang dilakukan adalah pendekatan perundang-undangan, dan pendekatan konsep. Pendekatan perundang-undangan dilakukan untuk meneliti aturan mengenai pengaturan tentang discrecionary power. Pendekatan konsep, dilakukan untuk memahami mengenai konsep-konsep discrecionary power dari berbagai pendapat para pakar hukum, sehingga diharapkan akan mendapat pemahaman yang jelas mengenai pentingnya penggunaan discrecionary power bagi

13 Johnny Ibrahim, Teori Dan Metodologi Penelitian Hukum Normatif , Edisi Revisi (Malang: Bayumedia Publishing, 2005), hlm 295 
pejabat pemerintah dalam upaya meningkatkan kualitas penyelenggaraan pemerintahan dan batasan yang dijadikan pedoman dalam penggunaan discrecionary power.

\section{Spesifikasi penelitian}

Spesifikasi penelitian yang akan dipergunakan adalah diskriptif analitis, yaitu menggambarkan peraturan perundang-undangan yang berlaku sebagai hukum positif dikaitkan dengan teori hukum dan praktek pelaksanaan hukum positif dalam masyarakat. ${ }^{14}$ Dengan demikian, untuk mendapatkan gambaran yang jelas mengenai pentingnya penggunaan discrecionary power bagi pejabat pemerintah dalam upaya meningkatkan kualitas penyelenggaraan pemerintahan dan batasan yang dijadikan pedoman dalam penggunaan discrecionary power, maka dalam penelitian ini akan diuraikan hasil-hasil penelitian sesuai dengan permasalahan dan tujuan yang akan dicapai serta menganalisisnya dari segi peraturan perundang-undangan yang berlaku yaitu UU Nomor 30 Tahun 2014 tentang Administrasi Pemerintahan, yang dikaitkan dengan teori-teori hukum yang ada, yaitu teori mengenai discrecionary power.

\section{Metode Pengumpulan Data}

Data yang dibutuhkan dalam penelitian ini adalah data sekunder. Data ini diambil dengan cara penelitian kepustakaan (Library Research). Data sekunder yang diambil meliputi bahan hukum primer dan bahan hukum sekunder.

Bahan hukum primer yaitu bahan hukum yang terdiri atas peraturan perundang-undangan yang diurut berdasarkan hierarkhi tata urutan perundang-undangan. ${ }^{15}$ Bahan hukum primer yang dipergunakan dalam penelitian ini adalah UU Nomor 30 Tahun 2014 tentang Administrasi Pemerintahan.

Bahan hukum sekunder adalah bahan hukum yang terdiri atas buku-buku teks yang ditulis para ahli hukum yang berpengaruh, jurnal-jurnal hukum, pendapat para sarjana, kasus-kasus hukum, yurisprudensi, dan hasil-hasil symposium mutakhir yang berkait dengan topik penelitian, ${ }^{16}$ yaitu pentingnya penggunaan discrecionary power bagi pejabat pemerintah dalam

\footnotetext{
${ }^{14}$ Bambang Sunggono, Metode Penelitian Hukum (Jakarta: PT. Raja Grafindo Persada, 2002), halaman. 36.

${ }^{15}$ Peter Mahmud Marzuki. Penelitian Hukum (Jakarta: Kencana, 2006), halaman 141

${ }^{16}$ Op.Cit, Ibrahim, halaman 296
} 
upaya meningkatkan kualitas penyelenggaraan pemerintahan dan batasan yang dijadikan pedoman dalam penggunaan discrecionary power.

\section{E. Metode Analis Data}

Metode analisis data dilakukan secara kualitatif, kemudian diidentifikasi dan dikategorisasi. Metode analisis kualitatif yaitu metode analisis yang pada dasarnya mempergunakan pemikiran logis, analitis, dengan logika induksi atau deduksi dengan analogi/intepretasi, komparasi dan sejenis itu. ${ }^{17}$ Sehingga bahan hukum yang telah diperoleh dalam penelitian kepustakaan ini, berupa aturan perundang-undangan dan artikel dimaksud penulis uraikan dan dihubungkan sedemikian rupa kemudian ditarik kesimpulan secara deduktif, yaitu menarik kesimpulan dengan berdasarkan pada dasar-dasar pengetahuan yang bersifat umum untuk mengkaji persoalanpersoalan yang bersifat khusus, sehingga hasilnya dapat disajikan dalam penulisan yang lebih sistematis guna menjawab permasalahan yang telah dirumuskan yaitu mengenai pentingnya penggunaan discrecionary power bagi pejabat pemerintah dalam upaya meningkatkan kualitas penyelenggaraan pemerintahan dan batasan yang dijadikan pedoman dalam penggunaan discrecionary power.

\section{HASIL DAN PEMBAHASAN}

\section{Pentingnya Penggunaan Discresionary Power Bagi Pejabat Pemeritah Dalam Upaya} Meningkatkan Kualitas Penyelenggaraan Pemerintahan,

Setiap negara hukum menuntut agar setiap penyelenggaraan pemerintahan harus didasarkan pada asas legalitas yaitu ketentuan undang - undang, hal ini bertujuan agar dapat menjamin kepastian hukum warga masyarakat. Namun dalam hal melaksanakan tugas dan kewajiban penyelenggaraan pemerintahan agar dapat memberikan dan menjaga kualitas pelayanan publik serta mengusahakan kesejahteraan (welfarestate), di samping memberikan jaminan dan perlindungan bagi warga negara, maka tidak bisa hanya berpegang pada asas legalitas, karena semakin hari, perkembangan tuntutan pelayanan publik semakin kompleks dan beragam. Permasalahan demi permasalahan muncul di masyarakat seperti halnya, misalnya dalam hal menghadapi suatu bencana alam gempa bumi sekala besar yang tidak dapat diprediksi sebelumnya, atau dalam menghadapi suatu wabah penyakit menular yang membutuhkan penanganan segera, maka aparat pemerintah harus segera mengambil tindakan

\footnotetext{
${ }^{17}$ Tatang A. Amirin, Menyusun Rencana Penelitian (Jakarta: C.V. Rajawali, 1986), halaman 95
} 
yang menguntungkan bagi negara maupun bagi rakyat. Tindakan yang diambil ini adalah tindakan yang mana diambil semata - mata timbul atas prakarsa sendiri, karena aturan undang - undangnya tidak ada. ${ }^{18}$

Contoh lain misalnya dalam hal pemberian izin berdasarkan Pasal $1 \mathrm{HO}$ atau izin gangguan, setiap pemberi izin bebas untuk menafsirkan pengertian "menimbulkan keadaan bahaya" sesuai dengan situasi dan kondisi daerah masing - masing. Tindakan ini dapat ditempuh oleh pejabat pemerintah dalam hal mana peraturan perundang - undangan yang menjadi dasar berbuat Pejabat Pemerintah memberikan kebebasan sepenuhnya. ${ }^{19}$

Misalnya lagi, dalam hal menggali sumber - sumber keuangan daerah. Pemerintah daerah bebas untuk mengelolanya, asalkan sumber - sumber itu merupakan sumber yang sah. Tindakan ini dapat ditempuh oleh pejabat pemerintah dalam hal adanya delegasi perundang undangan, maksudnya Pejabat Pemerintah diberi kekuasaan untuk mengatur sendiri, yang sebenarnya kekuasaan itu merupakan kekuasaan Pejabat yang lebih tinggi tingkatannya. ${ }^{20}$

Berdasarkan contoh kasus permasalahan - permasalahan yang muncul tersebut di atas, maka perlu suatu kebijakan dari pemerintah untuk mengatasinya, sehingga muncul prinsip bahwa:

"Pemerintah tidak boleh menolak untuk memberikan pelayanan kepada masyarakat dengan alasan tidak ada peraturan perundang - undangan yang mengaturnya, atau belum/tidak ada peraturan perundang - undangan yang dijadikan dasar kewenangan untuk melakukan perbuatan hukum". ${ }^{21}$ Oleh karena itu pemerintah diberikan kewenangan bebas melakukan tindakan / perbuatan tanpa harus terikat undang - undang yaitu diskresi.

Berdasarkan UU RI Nomor 30 Tahun 2014 tentang Administrasi Pemerintahan dijelaskan dalam Pasal 1 angka 9 bahwa diskresi adalah keputusan dan/atau tindakan yang ditetapkan dan/atau dilakukan oleh Pejabat Pemerintahan untuk mengatasi persoalan konkret yang dihadapi dalam penyelenggaraan pemerintahan dalam hal peraturan perundang-undangan yang memberikan pilihan, tidak mengatur, tidak lengkap atau tidak jelas, dan/atau adanya stagnasi pemerintahan.

\footnotetext{
${ }^{18}$ Op. Cit, Ridwan, halaman 172

${ }^{19}$ Ibid, halaman 172

${ }^{20}$ Ibid, halaman 172

${ }^{21}$ Ibid, halaman 172 - 173
} 
Berdasarkan pengertian di atas dapat dikatakan bahwa diskresi adalah suatu kebebasan bagi Pejabat Pemerintah untuk bertindak atau mengambil satu keputusan menurut pendapatnya sendiri dengan tujuan mengatasi permasalahan yang dihadapi dalam penyelenggaraan pemerintahan, tanpa terikat peraturan perundang - undangan dengan tujuan untuk:

1. Melancarkan penyelenggaraan pemerintahan;

2. Mengisi kekosongan hukum;

3. Memberikan kepastian hukum; dan

4. Mengatasi stagnasi pemerintahan dalam keadaan tertentu guna kemanfaatan dan kepentingan umum.

Bertitik tolak dari uraian di atas, penggunaan diskresi oleh Pejabat Pemerintah dalam praktik penyelenggaraan pemerintahan dipergunakan dalam hal belum ada peraturan perundang - undangan yang mengatur tentang penyelesaian in konkrito terhadap suatu masalah tertentu, padahal masalah tersebut menuntut penyelesaian dengan segera. Dengan kata lain dapat dikatakan bahwa pentingnya penggunaan diskresi bagi pejabat pemerintah agar tetap dapat menjaga kualitas penyelenggaraan pemerintahan berfungsi sebagai penunjang asas legalitas, atau dengan kata lain penggunaan diskresi ini berfungsi sebagai alternatif untuk mengisi kekurangan dan kelemahan di dalam penerapan asas legalitas.

Walaupun pemerintah diberikan kewenangan untuk bertindak bebas, namun penggunaan diskresi dalam suatu negara hukum, tidaklah dipergunakan tanpa batas. Penggunaan diskresi harus dalam batas - batas yang dimungkinkan oleh hukum yang berlaku (batasan yuridis). Dalam sub bab selanjutnya akan diuraikan mengenai batasan bagi pejabat pemerintah dalam menggunakan diskresi.

\section{Batasan Bagi Pejabat Pemerintah Dalam Menggunakan Discresionary Power Dalam Upaya Meningkatkan Kualitas Penyelenggaraan Pemerintahan}

Discresionary power yang sering disebut dengan istilah diskresi, lahir karena bertolak dari kewajiban pemerintah dalam kerangka mencapai suatu negara sejahtera (welfare state), di mana tugas yang utama adalah memberikan pelayanan umum atau mengusahakan kesejahteraan bagi warga negara, di samping memberikan perlindungan bagi warga negara. ${ }^{22}$ Di Negara Indonesia diskresi lahir bersamaan dengan pemberian tugas kepada pemerintah

${ }^{22} \mathrm{Ibid}$, halaman 172 
untuk merealisasikan tujuan negara seperti yang tercantum dalam Alinea ke IV Pembukaan UUD NRI Tahun 1945, yaitu sebagai berikut:

a. Melindungi segenap Bangsa Indonesia dan seluruh tumpah darah Indonesia

b. Memajukan kesejahteraan umum

c. Mencerdaskan kehidupan bangsa, dan

d. Ikut melaksanakan ketertiban dunia, perdamaian abadi dan keadilan sosial.

Bertitik tolak dari tujuan negara tersebut di atas, maka tugas utama pemerintah dalam konsepsi welfare state itu memberikan pelayanan bagi warga negara semaksimal mungkin. Sehingga muncul sebuah prinsip bahwa pemerintah tidak boleh menolak untuk memberikan pelayanan kepada masyarakat dengan alasan tidak ada peraturan perundang - undangan yang mengaturnya atau belum / tidak ada peraturan perundang - undangan yang dijadikan dasar kewenangan untuk melakukan perbuatan hukum. Oleh karenanya setiap Pejabat Pemerintah yang berwenang diberikan sebuah diskresi, sehingga tetap dapat menjaga kualitas penyelenggaraan pemerintahan dengan baik.

Sehubungan dengan diskresi yang diberikan kepada Pejabat Pemerintah, dalam kerangka negara hukum, penggunaan diskresi bagi pejabat pemeritah dalam upaya meningkatkan kualitas penyelenggaraan pemerintahan harus dalam batas - batas yang dimungkinkan oleh hukum yang berlaku. Menurut Sjachran Basah, mengemukakan pendapat mengenai penggunaan diskresi harus dapat dipertanggung-jawabkan secara moral kepada Tuhan Yang Maha Esa, menjunjung tinggi harkat dan martabat manusia serta nilai - nilai kebenaran dan keadilan, mengutamakan persatuan dan kesatuan demi kepentingan bersama. ${ }^{23}$ Selain itu Sjachran Basah, mengatakan bahwa secara hukum penggunaan diskresi terdapat 2 (dua) batas, yaitu batas atas dan batas bawah.:

a. Batas atas, dimaksudkan ketaat-asasan ketentuan perundang - undangan berdasarkan asas taat asas, yaitu peraturan yang tingkat derajatnya lebih rendah tidak boleh bertentangan dengan peraturan yang tingkat derajatnya lebih tinggi.

b. Batas bawah, adalah peraturan yang dibuat atau sikap - tindak administrasi negara (baik aktif maupun pasif), tidak boleh melanggar hak dan kewajiban asasi warga. ${ }^{24}$

Selain menurut Sjachran Basah, ada pakar yang bernama Muchsan, mengemukakan batasan penggunaan diskresi bagi pejabat pemeritah dalam upaya meningkatkan kualitas penyelenggaraan pemerintahan:

a. Tidak boleh bertentangan dengan sistem hukum yang berlaku (kaidh hukum positif).

${ }^{23}$ Ibid, Ridwan, halaman 173

${ }^{24}$ Ibid, Ridwan, halaman 173 
b. Hanya ditujukan demi kepentingan umum. ${ }^{25}$

Sehubungan dengan batasan penggunaan diskresi bagi pejabat pemeritah dalam upaya meningkatkan kualitas penyelenggaraan pemerintahan, dari kedua pendapat di atas, maka dapat disimpulkan bahwa penggunaan diskresi tidak boleh dengan peraturan perundangundangan yang berlaku, ditujukan untuk kepentingan umum dan tidak boleh melanggar hak asasi warga masyarakat.

Selain pendapat para pakar tersebut di atas, di Negara Indonesia, batasan penggunaan diskresi bagi pejabat pemeritah dalam upaya meningkatkan kualitas penyelenggaraan pemerintahan dibatasi oleh peraturan perundang - undangan, yaitu UU Administrasi Pemerintahan. Berdasarkan Pasal 22 UU Administrasi Pemerintahan, dijelaskan bahwa diskresi hanya dapat dilakukan oleh Pejabat Pemerintahan yang berwenang, dengan tujuan untuk:

a. Melancarkan penyelenggaraan pemerintahan;

b. Mengisi kekosongan hukum;

c. Memberikan kepastian hukum; dan

d. Mengatasi stagnasi pemerintahan dalam keadaan tertentu guna kemanfaatan dan kepentingan umum.

Selanjutnya dijelaskan lebih lanjut dalam Pasal 23 UU Administrasi Pemerintahan bahwa ruang lingkup penggunaan diskresi Pejabat Pemerintahan tersebut hanya meliputi:

a. Pengambilan keputusan dan/atau tindakan berdasarkan ketentuan peraturan perundang-undangan yang memberikan suatu pilihan keputusan dan/atau tindakan;

b. Pengambilan keputusan dan/atau tindakan karena peraturan perundang-undangan tidak mengatur;

c. Pengambilan keputusan dan/atau tindakan karena peraturan perundang-undangan tidak lengkap atau tidak jelas;

d. Pengambilan keputusan dan/atau tindakan karena adanya stagnasi pemerintahan guna kepentingan yang lebih luas.

Kemudian penggunaan diskresi bagi pejabat pemeritah dalam upaya meningkatkan kualitas penyelenggaraan pemerintahan harus memenuhi persyaratan sesuai Pasal 24 dan 25

UU Administrasi Pemerintahan, yaitu sebagai berikut:

a. Sesuai dengan tujuan diskresi

b. Tidak bertentangan dengan ketentuan peraturan perundang-undangan;

c. Sesuai dengan Asas - Asas Umum Pemerintahan yang Baik;

d. Berdasarkan alasan-alasan yang objektif;

e. Tidak menimbulkan Konflik Kepentingan; dan

f. Dilakukan dengan iktikad baik.

${ }^{25}$ Ibid, Ridwan, halaman 173 
g. Penggunaan diskresi yang berpotensi mengubah alokasi anggaran serta menimbulkan akibat hukum yang berpotensi membebani keuangan negara, wajib memperoleh persetujuan dari Atasan Pejabat sesuai dengan ketentuan peraturan perundangundangan.

h. Dalam hal penggunaan diskresi menimbulkan keresahan masyarakat, keadaan darurat, mendesak dan/atau terjadi bencana alam, Pejabat Pemerintahan wajib memberitahukan kepada Atasan Pejabat sebelum penggunaan diskresi dan melaporkan kepada Atasan Pejabat setelah penggunaan diskresi.

Selain harus memenuhi berbagai macam persyaratan seperti yang telah disebutkan di atas, Pejabat Pemerintah yang akan menggunakan diskresi, juga harus melewati prosedur yang telah ditetapkan dalam Pasal 26, 27, 28 dan 29

UU Administrasi Pemerintahan, yaitu:

a. Pejabat yang akan menggunakan diskresi apabila berpotensi mengubah alokasi anggaran dan menimbulkan akibat yang berpotensi membebani keuangan negara wajib:

1) Menguraikan maksud, tujuan, substansi, serta dampak administrasi dan keuangan.

2) Menyampaikan permohonan persetujuan secara tertulis kepada Atasan Pejabat

b. Pejabat yang akan menggunakan diskresi apabila berpotensi menimbulkan keresahan masyarakat, keadaan darurat, mendesak dan / atau terjadi bencana alam wajib:

1) Menguraikan maksud, tujuan, substansi, dan dampak yang ditimbulkan.

2) Wajib menyampaikan laporan secara tertulis kepada Atasan Pejabat setelah penggunaan diskresi.

3) Pelaporan disampaikan paling lama 5 (lima) hari kerja terhitung sejak penggunaan diskresi

c. Pejabat yang menggunakan diskresi tidak perlu memberitahukan kepada warga masyarakat, kecuali diskresi yang akan dilakukan berkaitan dengan keputusan dan/atau tindakan yang menimbulkan kerugian.

Selain batasan penggunaan diskresi bagi pejabat pemeritah dalam upaya meningkatkan kualitas penyelenggaraan pemerintahan yang telah diuraikan di atas, terdapat batasan lainnya, yaitu berupa asas - asas penyelenggaraan pemerintahan atau yang dikenal dengan istilah AAUPB. Menurut Jazim Hamidi AAUPB adalah:

a. Merupakan nilai - nilai etik yang hidup dan berkembang dalam lingkungan Hukum Administrasi Negara.

b. AAUPB berfungsi sebagai pegangan bagi pejabat administrasi negara dalam menjalankan fungsinya, merupakan alat uji bagi hakim administrasi dalam menilai tindakan administrasi negara (yang berwujud penetapan/beschikking), dan sebagai dasar pengajuan gugatan bagi pihak penggugat.

c. Sebagian besar AAUPB masih merupakan asas - asas yang tidak tertulis, masih abstrak, dan dapat digali dalam praktik kehidupan di masyarakat. 
d. Sebagian asas yang lain sudah menjadi kaidah hukum tertulis dan terpencar dalam berbagai peraturan hukum positif. Meskipun sebagian dari asas itu berubah menjadi kaidah hukum tertulis, namun sifatnya tetap sebagai asas hukum. ${ }^{26}$

Sedangkan dalam Pasal 1 angka 17 UU Administrasi Pemerintahan, dijelaskan bahwa Asas-asas Umum Pemerintahan yang Baik yang selanjutnya disingkat AUPB adalah prinsip yang digunakan sebagai acuan penggunaan wewenang bagi Pejabat Pemerintahan dalam mengeluarkan keputusan dan/atau tindakan dalam penyelenggaraan pemerintahan.

Bertitik tolak dari pengertian di atas, maka dapat disimpulkan bahwa AAUPB adalah asas - asas umum yang dijadikan prinsip dasar dan tata cara atau pedoman dalam penyelenggaraan pemerintahan, yang dengan cara demikian penyelenggaraan pemerintahan itu menjadi baik, sopan, adil, dan terhormat, bebas dari kezaliman, pelanggaran peraturan, tindakan / perbuatan penyalahgunaan wewenang dan tindakan / perbuatan yang sewenang - wenang.

AAUPB ini merupakan sebuah konsep terbuka (open begrip), oleh karenanya AAUPB akan berkembang dan disesuaikan dengan ruang dan waktu di mana konsep ini berada. Sehingga AAUPB ini secara kontemplatif maupun aplikatif bisa berbeda - beda antara negara yang satu dengan negara yang lain. Untuk di Negara Indonesia AAUPB diatur dalam Pasal 10 UU Administrasi Pemerintahan. Di dalam Pasal ini dijelaskan bahwa AAUPB meliputi:

a. Kepastian hukum

Yang dimaksud dengan asas kepastian hukum adalah asas dalam negara hukum yang mengutamakan landasan ketentuan peraturan perundang-undangan, kepatutan, keajegan, dan keadilan dalam setiap kebijakan penyelenggaraan pemerintahan.

b. Kemanfaatan

Yang dimaksud dengan asas kemanfaatan adalah manfaat yang harus diperhatikan secara seimbang antara:

a) Kepentingan individu yang satu dengan kepentingan individu yang lain;

b) Kepentingan individu dengan masyarakat;

c) Kepentingan Warga Masyarakat dan masyarakat asing;

d) Kepentingan kelompok masyarakat yang satu dan kepentingan kelompok masyarakat yang lain;

e) Kepentingan pemerintah dengan Warga Masyarakat;

f) Kepentingan generasi yang sekarang dan kepentingan generasi mendatang;

g) Kepentingan manusia dan ekosistemnya;

h) Kepentingan pria dan wanita.

c. Ketidakberpihakan

${ }^{26}$ Op. Cit. Jazim Hamidi, halaman 24. 
Yang dimaksud dengan asas ketidakberpihakan adalah asas yang mewajibkan Badan dan/atau Pejabat Pemerintahan dalam menetapkan dan/atau melakukan Keputusan dan/atau Tindakan dengan mempertimbangkan kepentingan para pihak secara keseluruhan dan tidak diskriminatif.

\section{d. Kecermatan}

Yang dimaksud dengan asas kecermatan adalah asas yang mengandung arti bahwa suatu Keputusan dan/atau Tindakan harus didasarkan pada informasi dan dokumen yang lengkap untuk mendukung legalitas penetapan dan/atau pelaksanaan Keputusan dan/atau Tindakan sehingga Keputusan dan/atau Tindakan yang bersangkutan dipersiapkan dengan cermat sebelum Keputusan dan/atau Tindakan tersebut ditetapkan dan/atau dilakukan.

e. Tidak menyalahgunakan kewenangan

Yang dimaksud dengan asas tidak menyalahgunakan kewenangan adalah asas yang mewajibkan setiap Badan dan/atau Pejabat Pemerintahan tidak menggunakan kewenangannya untuk kepentingan pribadi atau kepentingan yang lain dan tidak sesuai dengan tujuan pemberian kewenangan tersebut, tidak melampaui, tidak menyalahgunakan, dan/atau tidak mencampuradukkan kewenangan.

\section{f. Keterbukaan}

Yang dimaksud dengan asas keterbukaan adalah asas yang melayani masyarakat untuk mendapatkan akses dan memperoleh informasi yang benar, jujur, dan tidak diskriminatif dalam penyelenggaraan pemerintahan dengan tetap memperhatikan perlindungan atas hak asasi pribadi, golongan, dan rahasia negara.

\section{g. Kepentingan umum}

Yang dimaksud dengan asas kepentingan umum adalah asas yang mendahulukan kesejahteraan dan kemanfaatan umum dengan cara yang aspiratif, akomodatif, selektif, dan tidak diskriminatif.

h. Pelayanan yang baik.

Yang dimaksud dengan asas pelayanan yang baik adalah asas yang memberikan pelayanan yang tepat waktu, prosedur dan biaya yang jelas, sesuai dengan standar pelayanan, dan ketentuan

peraturan perundang-undangan. 
Asas-asas umum lainnya di luar AUPB yang telah disebutkan di atas seperti asas umum pemerintahan yang baik yang bersumber dari putusan pengadilan negeri yang tidak dibanding, atau putusan pengadilan tinggi yang tidak dikasasi atau putusan Mahkamah Agung, dapat diterapkan sepanjang dijadikan dasar penilaian hakim yang tertuang dalam putusan Pengadilan yang berkekuatan hukum tetap.

Berdasarkan uraian di atas, maka dapat disimpulkan bahwa penggunaan diskresi bagi pejabat pemeritah dalam upaya meningkatkan kualitas penyelenggaraan pemerintahan dibatasi oleh peraturan perundang - undangan yang di dalamnya memuat berbagai macam persyaratan dan prosedur serta asas - asas yang harus dijadikan pedoman, sehingga kualitas penyelenggaraan pemerintahan itu menjadi baik, sopan, adil, dan terhormat, bebas dari kezaliman, pelanggaran peraturan, tindakan / perbuatan penyalahgunaan wewenang dan tindakan / perbuatan yang sewenang - wenang.

\section{SIMPULAN}

1. Pentingnya penggunaan discresionary power bagi pejabat pemeritah dalam penyelenggaraan pemerintahan adalah sebagai alternatif untuk mengisi kekurangan dan kelemahan di dalam penerapan asas legalitas (wetmatigheid van bestuur), agar di samping pemerintah dapat melindungi dan menjamin kepastian hukum warga negara, pemerintah juga dapat memberikan pelayanan publik dan kesejahteraan bagi warga negara.

2. Batasan bagi pejabat pemerintah dalam menggunakan Discresionary Power dalam upaya meningkatkan kualitas penyelenggaraan pemerintahan adalah sebuah peraturan perundang undangan yang di dalamnya memuat berbagai macam persyaratan dan prosedur serta asas asas penyelenggaraan pemerintahan.

\section{SARAN}

Adapun saran yang dapat dikemukakan oleh peneliti setelah memperoleh kesimpulan dari pembahasan adalah bahwa sebaiknya setiap pejabat pemerintah ketika hendak menggunakan diskresi dalam melaksanakan tugas penyelenggaraan pemerintahan harus memperhatikan batasan - batasan yang telah ditetapkan, sehingga tindakan / perbuatan yang dilakukan tidak melampaui 
wewenang dan sewenang - wenang, agar tidak merugikan negara dan masyarakat, dengan demikian ada pertanggungjawaban dari setiap tindakan / perbuatan yang telah dilakukan.

\section{DAFTAR PUSTAKA}

Admosudirdjo, Prajudi. Penegakan Hukum Di Lapangan Oleh Polri. Jakarta: Dinas Hukum Polri, 1997.

A Garner, Bryan. Black's Law Dictionary Seven Edition. West Group: ST. PAUL, MINN, 1999. Asyhadie, H. Zaeni, dkk. Pengantar Hukum Indonesia. Jakarta: PT. Raja Grafindo Persada, 2015.

Aaron, Thomas J. Penyaringan Perkara Pidana Oleh Polisi (Diskresi Kepolisian), Cetakan Pertama. Jakarta: PT. Pradnya Paramita, 1991.

Ibrahim, Johnny. Teori Dan Metodologi Penelitian Hukum Normatif, Edisi Revisi. Malang: Bayumedia Publishing, 2005.

Marzuki, Peter Mahmud. Penelitian Hukum. Jakarta: Kencana, 2006.

Ridwan. Hukum Administrasi Negara Edisi Revisi. Jakarta: PT. Raja Grafindo Persada, 2014.

Sunggono, Bambang. Metode Penelitian Hukum. Jakarta, PT. Raja Grafindo Persada, 2002.

Sukanto, Soerjono. Pengantar Penelitian Hukum. Jakarta: UI Press, 1984.

\section{UNDANG - UNDANG}

Sekretariat Negara RI, Undang - Undang Nomor 30 Tahun 2004 tentang Administrasi Pemerintahan. Jakarta, 2004. 